Post-print of Cucchi C. 2019, National Cultures on European Corporate Homepages in English: A Linguistic Analysis, International Journal of Business Communication, 56(2) 198-232, DOI: 10.1177/2329488415604456.

Published Online first in 2015.

Costanza Cucchi

Università Cattolica del Sacro Cuore, Milan

\title{
National cultures on European corporate homepages in English: A linguistic analysis
}

\begin{abstract}
The aim of the study is to discover linguistic features that may be related to national differences on European corporate websites where English is used as a lingua franca.

The methodology used is qualitative and corporate homepages are taken as units of analysis. European cheese companies are chosen due to the links between food and national identity and to the importance of the cheese sector in Europe. Four European countries - Austria, Denmark, Poland and Portugal - are selected in order to represent different national cultures within three different geographic areas, namely Northern, Central and Southern Europe.

Findings reveal, firstly, significant differences in the kind of information provided and in the linguistic features used and, secondly, that a number of differences can be explained with reference to Hall's (Hall \& Reed Hall, 1990) and Hofstede's (Hofstede, Hofstede, \& Minkov, 2010) cultural models.

The study shows that linguistic research can contribute considerably to marketing studies, by identifying linguistic markers that could be associated with cultural dimensions and by illustrating how they interact in actual website texts.
\end{abstract}

Keywords: corporate homepages; Hall's and Hofstede's model; genre analysis; BELF ; language and culture 


\section{Introduction and Literature Review}

Corporate websites are powerful channels through which companies can convey their identity to a potentially global audience, thus increasing their visibility worldwide by reaching a diversified audience in terms of language and culture. To reach this goal, companies can either set up a localised website with versions in different languages targeting different national markets, or utilise one or more lingue franche in addition to the national language.

In the field of linguistics, one strand of research investigates whether the localised versions in English of the same corporate website project a unified corporate image. Turnbull (2011), for example, compares six localised versions of the 'About us' section of the Uniliver website, while Cesiri (2011) analyses four localised versions of the presentation pages of Nestlé and Kraft. Another strand of research focuses on the versions in English as a Lingua Franca (ELF) of national corporate websites. For example, Aaltonen (2005) deals with the deviations from Standard English in the ELF versions of Finnish corporate websites. Gatti (2011) analyses the typical features of the history section of the websites of the top Baltic companies and Gatti (2013) investigates corporate identity metaphors in the English web versions of the top Italian companies. Isaksson and Jørgensen (2010) contrast the websites of British, Danish and Norwegian PR companies, while Turnbull (2008) and Facchinetti (2013) compare the English websites of national British companies and the ELF versions of national Italian companies.

Recent studies in the field of marketing also focus on localised websites and websites in ELF, aiming to unveil cross-cultural differences in terms of web design, navigation tools, imagery and the availability of specific information such as organisational charts and job opportunity descriptions, and relate the investigated features to Hall's and Hofstede's cultural models. Examples of studies based on Hall's model are Würtz (2005) and Usunier and Roulin (2010). Robbins and Stylianou (2001) and Avery, Baradwaj, and Singer (2008) refer to Hofstede's model, while Singh's studies (Singh, Zhao, \& Hu, 2003; Singh, Zhao, \& Hu, 2005; Singh \& Pereira, 2005; Baack \& Singh, 2007) combine the two models. Despite globalisation, findings from these studies show the existence of differences in website styles on a country-basis.

Some of the above-mentioned marketing studies contain remarks on the themes dealt with on websites, such as tradition (Singh Zhao, \& Hu, 2005: 145-146; Baack \& Singh 2007: 184), and on the use of forms, such as personalisation, which is measured by the "presence or absence of [...] content that contained such personalizing words as 'I', 'my', 'you' and 'your'" (Zhao, Massey, Murphy, \& Fang, 2003, p. 78). However, given that the studies are conducted within the field of marketing, there is currently a lack of a detailed analysis of relevant communicative and linguistic aspects.

In linguistics, Hofstede's and Hall's models have recently been applied in various works. For example, Clyne (1994), Hatipoğlu (2006), Bjørge (2007), Loukianenko Wolfe (2008) and Poppi (2012) refer to Hofstede's framework. Examples of studies which use Hall's framework are Vasta (1999) and Vergaro (2004). Katan (2006), Guillén-Nieto (2009), Conaway and Wardrope (2010), Cucchi (2010a), Manca (2012) refer to both cultural frameworks ${ }^{1}$. Curiously, to the best of my knowledge, no studies, except CUCCHI (2010b, 2012), rely on cultural models to study linguistic cross-cultural differences in corporate websites.

The present investigation aims to identify the salient formal and content features of the corporate websites of selected national and local companies in Europe, a geographically delimited territory, in which, it could be claimed, cultural differences tend to be blurred. A further purpose of the present study is to discuss whether the linguistic and communicative features identified may be explained with reference to Hall's and Hofstede's models, comparing the findings with those pointed out in existing literature. As observed by Fletcher (2006, p. 266), in fact, Hall's and Hofstede's models were devised "before the recent revolution in cross border communication, the accelerated

\footnotetext{
${ }^{1}$ For a discussion of some of these works, see AUTHOR, 2011.
} 
movement of peoples between countries, the rising level of globalization and the information revolution led by the internet" and "[ $\mathrm{t}]$ his raises the question as to whether their resulting dimensions are as relevant in the new millennium as when they were originally developed".

\section{Methodological issues and Data Collection}

The companies considered are national and local because it is assumed that, if they exist, national preferences in terms of form and content are more visible in their website discourse than they are on the websites of multinationals. Compared to the latter, national and local companies generally have more limited financial resources to invest in the foreign versions of their websites and are therefore more likely to rely on translations from their mother tongue, without further adaptation.

In order to investigate the website homepages of European companies, a corpus of data was compiled. The countries to be included were selected with reference to Hofstede's model. The model, first illustrated in Hofstede (1980), relies on the assumption that people from all countries share the same problems but the responses given to them tend to differ on the basis of nationality. The differences among countries are expressed through scores attributed to nations along cultural dimensions, a dimension being "an aspect of a culture which can be measured relative to other cultures" (Hofstede, 2003, p. 14). The country scores, in turn, derive from questionnaires on workplace values given to employees working in IBM subsidiaries in different countries between 1967 and 1973. Due to their different scores along Hofstede's dimensions, Austria, Denmark, Poland and Portugal were selected. The four countries also represent the three geographical areas into which the European countries were classified in Hofstede's model (Hofstede, Hofstede, \& Minkov, 2010): Europe North-Anglo, Europe Central/East ex-Soviet and Europe South/South East.

It is worth mentioning that, despite the fact that comparison among countries is much more convenient compared to Hall's model (Hall, 1976; Hall \& Reed Hall, 1990), which "is not based on any published statistics" (Katan, 2004, p. 253), and that the number of countries considered is much larger, Hofstede's model is not unchallenged. For example, McSweeney (2002) is a detailed analysis of the weaknesses in Hofstede's assumptions and methodology. In turn, McSweeney's (2002) critiques are discussed in Williamson (2002). According to McSweeney, one of the flaws in Hofstede's model is the assumption that individuals share "a common national culture" (p. 93, emphasis in the original). Williamson (2002, p. 1378) claims that this critique is inconsistent with Hofstede's methodology, in that Hofstede "found considerable variety of responses among individuals in a country and considerable overlap in responses of individuals from different countries", which is compatible with the existence of a variety of cultural values in individuals within a country. As pointed out by Williamson, Hofstede himself was aware of the ecological fallacy, consisting in predicting the values of single individuals on the basis of their nationality, and clarified that his scores are based on average responses. As such, in Williamson's words (p. 1381), "scores can only be a very rough indication of tendencies in the rich variety of cultural values".

Although potential users of websites range from loyal customers and casual visitors to investors and competitors and these, in turn, will certainly vary, for example, in terms of interests, professions and age, Singh and Pereira (2005, p. X) claim that it is appropriate to adopt a country-based approach for website localisation because "global businesses continue to use 'countries' as a basis for segmenting and targeting global customers (e.g. companies talk in terms of 'entering the Chinese market')". Similarly, in order to reach the highest possible number of users, national and local companies are likely to target average, idealised users of a country. Therefore, for the study of websites it seems appropriate to rely on Hofstede's and Hall's model, which both equate culture with nationality, thus simplifying both the diverse cultures which each single individual carries and which are represented within a single nation. 
Companies were chosen in the food sector, given the centrality of food in today's society. Food is the theme of Expo 2015, claimed to be "an extraordinary universal event displaying tradition, creativity and innovation in the business of food"2. Among the topics suggested for debate in Expo 2015 is "[e]nhancing the value of cultural and ethnic heritage as expressed in culinary traditions", which clearly indicates a link between food and culture. In linguistics, according to Turnbull (2008, p. 18), the food and drink sectors are "the natural candidates for a study of cultural and national identities in websites".

Within the food sector, cheese products were selected given their importance in Europe. The European Food Information Council (EUFIC) claims that "[c]heese is synonymous with Europe"4 Both EUFIC and the European Dairy Association (EDA) mention the centrality of cheese as a part of a healthy $\operatorname{diet}^{5}$ for Europeans. In addition, EUFIC reports that "European countries dominate both the world's production and consumption of this popular food" ${ }^{\prime \prime}$ and The Dairy Site indicates the EU cheese market as "the largest in the world"

The next step was to establish a criterion for the selection of company websites. As pointed out in Isakksson and Jørgensen (2010, p. 128), who studied the websites of public relations companies, it is very difficult to "develop[...] a workable method to identify representative [...] discourse in an erratic Web site universe". However, this was considered a crucial step to ensure comparability or, at least, to limit potential errors in interpretation deriving from the comparison of web texts from inadequate sources. Due to its institutional importance at a supranational level, it was decided to rely on the website of the European Dairy Association (EDA) ${ }^{8}$, which portrays itself as "represent[ing] the interests of the European dairy industry towards the European Institutions (the Commission, Parliament, Council of Ministers, Economic and Social Committee...) as well as to the international bodies (the Codex Alimentarius, the World Trade Organisation...)".9"

The EDA website offers a list of national dairy associations ${ }^{10}$, which are here assumed to be representative of the dairy sector in each country. In turn, the national dairy associations provide a list of their members. Companies which did not deal with cheese as well as multinational cheese companies were cut from the list since they did not satisfy the criteria of the present investigation. Once a list of local dairy companies was obtained, it was checked whether their websites had a version in English. The results are illustrated in Table 1.

\begin{tabular}{|c|c|c|c|}
\hline National associations & EDA Members & $\begin{array}{c}\text { National dairy } \\
\text { corporate websites }\end{array}$ & $\begin{array}{c}\text { Websites with an } \\
\text { English version }\end{array}$ \\
\hline VÖM Austrian Dairy Association $^{11}$ & 16 & 11 & $9(82 \%)$ \\
\hline Danish Dairy Board $^{12}$ & 33 & 13 & $4(31 \%)$ \\
\hline PIM Polish Chamber of Milk $^{13}$ & 64 & 13 & $8(62 \%)$ \\
\hline $\begin{array}{c}\text { ANIL Portuguese National } \\
\text { Association of Dairy Products }^{14}\end{array}$ & 42 & 18 & $4(22 \%)$ \\
\hline
\end{tabular}

Table 1. National websites with an English version

\footnotetext{
${ }^{2}$ http://en.expo2015.org/theme

3 ibidem

${ }^{4}$ http://www.eufic.org/article/en/nutrition/salt/artid/Cheese-European-tradition/

${ }^{5}$ Ibidem. http://www.euromilk.org/eda/content_html.aspx?cid=426

${ }^{6} \mathrm{http} / / / \mathrm{www}$. eufic.org/article/en/nutrition/salt/artid/Cheese-European-tradition/

${ }^{7} \mathrm{http}: / / \mathrm{www}$.thedairysite.com/articles/2875/european-cheese-market

${ }^{8} \mathrm{http}$ ://www.euromilk.org/eda/index.aspx

${ }^{9} \mathrm{http}: / /$ www.euromilk.org/eda/content_html.aspx? $\mathrm{cid}=13$

${ }^{10}$ Available at http://www.euromilk.org/eda/members.aspx? cid=15

${ }^{11} \mathrm{http}: / / \mathrm{www}$.voem.or.at/index.php?id=9

${ }^{12} \mathrm{http}: / / \mathrm{www} . \mathrm{mejeri.dk/}$

${ }^{13} \mathrm{http} / / /$ izbamleka.pl/about/members-of-polish-chamber-of-milk/

${ }^{14} \mathrm{http}: / / \mathrm{www}$.anilact.pt/anil/associados
} 
As shown in Table 1, the number of websites with an English version was not equal in the four countries, which may be viewed as a disadvantage for comparability purposes. However, this had the advantage of offering a snapshot of the spread of English as a lingua franca in the dairy sector of the countries considered, as represented by the members of the national organisations. While nearly all Austrian cheese producers and most Polish producers have a website with a version in English, the percentage is considerably lower in Denmark and Portugal. The final composition of the corpus is illustrated in Table 2.

\begin{tabular}{|l|l|}
\hline Austrian companies & Polish companies \\
1 Ennstal & 1 Kalisz \\
2 Gmunder & 2 Łowicz \\
3 Kärtnermilch & 3 Mlekovita \\
4 Pinzgaumich & 4 Piątnica \\
5 Rupp & 5 Polmlek Group \\
6 Schärdiger & 6 Rotr \\
7 Voralberg Milch & 7 Sertop \\
8 Woerle & 8 Spomlek \\
9 Zillertal & \\
\hline Danish companies & Portuguese companies \\
& \\
1 Barrit & 1 Indulac \\
2 St. Clemens & 2 Insulac \\
3 Mammen Dairy & 3 Lacticinios Paiva \\
4 Sædager & 4 Saloio \\
\hline
\end{tabular}

Table 2. Composition of the corpus

The unit of analysis adopted in the present investigation is the homepage, defined as "the first page or computer screen of information that a viewer sees when accessing a website" (Zhao, Massey, Murphy, \& Fang, 2003, p. 78). As observed by Turnbull (2008, p. 19), the homepage "is a fundamental part of the website because it acts as a reception hall and has to entice visitors in and also make them stay". In addition, Jones (2007, p. 241) reports that "most users do not scroll beyond the first screen of a homepage".

Methodologically, the present study differs from the ones conducted in the field of marketing in two important ways. First, marketing studies which apply Hofstede's and Hall's models start from a list of design and content features decided in advance, which are later associated to Hofstede's and Hall's dimensions by independent coders. On the contrary, the present study moves from a close qualitative observation of the linguistic features ${ }^{15}$ characterising corporate homepages conducted by a single analyst. If this analysis is inevitably more subjective, it enables to identify linguistic features which may be missed when starting from a predetermined list. Secondly, while the marketing studies considered for the present investigation provide scant linguistic data, the present study presents a wealth of data, as is customary in linguistics research.

\footnotetext{
${ }^{15}$ For readers outside the field of linguistics, it is here specified that 'linguistic features' is a broad term encompassing, for example, choice of lexis, textual arrangement, the degree of explicitness and of formality.
} 


\section{The context}

Prior to the homepage analysis, this Section presents the broad cultural context, with reference to Hofstede's and Hall's scores along the cultural dimensions in the four countries. After that, contextual data on the companies' local character and on their role in the international market is discussed.

\section{A cultural profile of the four countries}

As already stated, the four European countries object of analysis were chosen on the basis of their significantly different scores on Hofstede's multidimensional model. The dimensions are briefly introduced below.

The four original dimensions are Individualism (IDV), Power Distance (PD), Uncertainty Avoidance (UA) and Masculinity (MAS). IDV is the tendency of individuals to take care of themselves and is opposed to Collectivism (COL), implying a broader interest in the well-being of the people belonging to one's in-group. PD is the degree to which people tolerate an unequal distribution of power within societies, while UA measures the tolerance of ambiguous and unknown situations. MAS is the tendency to assertiveness and is opposed to femininity (FEM), a tendency to more modest behaviour.

In 1985 a sixth dimension, Long Term Orientation (LTO) versus Short Term Orientation (STO), was found and added to the model. In Hofstede's words, LTO "stands for the fostering of virtues oriented towards future rewards, in particular, perseverance and thrift", while STO "stands for the fostering of virtues related to the past and the present, in particular respect for tradition, preservation of 'face' and fulfilling of social obligations" (Hofstede, 2001, p. 359). Since this dimension emerged from the Chinese Value Survey, which investigated typically Eastern values, Hofstede himself warns that, unsurprisingly, "[t]he values that together form the new dimension will probably puzzle many Western readers" because "the dimension is composed precisely of elements that Western questionnaires had not registered" (Hofstede, 2001, p. 355).

A further dimension, Indulgence versus Restraint (IVR) was added in 2010. Indulgence is defined as "a tendency to allow relatively free gratification of basic and natural human desires related to enjoying life and having fun", while Restraint "reflects a conviction that such gratification needs to be curbed and regulated by strict social norms" (Hofstede, Hofstede, \& Minkov, 2010, p. 281).

The scores of the four countries are illustrated in Table 3. For an interpretation of the scores, it should be noted that cultural dimensions are measured on a scale from 1 to 100 and that the countries which were added later to the model may score beyond 100, since their scores were found to be higher than those of the countries previously considered. Scores below 50 are conventionally indicated as low, those above 50 are considered high.

\begin{tabular}{|c|c|c|c|c|}
\hline Hofstede's scores & Austria & Poland & Denmark & Portugal \\
\hline IDV & 55 & 60 & 74 & 27 \\
\hline PD & 11 & 68 & 18 & 63 \\
\hline UA & 70 & 93 & 23 & 104 \\
\hline MAS & 79 & 64 & 16 & 31 \\
\hline LTO & 60 & 38 & 35 & 28 \\
\hline IVR & 63 & 29 & 70 & 33 \\
\hline
\end{tabular}

Table 3. Scores on Hofstede's cultural dimensions

Portugal's score on IDV (27) is very low, Serbia being the only country in Europe whose IDV (25) is lower. Loyalty and commitment to the members of the in-group and to one's family are 
particularly important values. On the contrary, Austria, Denmark and Poland all score above 50 on IDV, which indicates that individuals' initiatives and responsibility are more valued.

Austria is the country which scores lowest on PD (11) in Hofstede's research, which implies that power asymmetries tend to be disliked and avoided. While Denmark's PD (18) is also very low, being the third lowest after Austria and Israel, both Poland and Portugal score above 50 and can therefore be characterised as hierarchical societies. Since 70 is the maximum PD score in Hofstede's research, Poland's score (68) is very high, besides being, with France (68), the highest in Europe.

Portugal's UA score (104) is very high, exceeded only by Greece (112). This implies that norms are highly valued as means of reducing ambiguities and uncertainty. Poland's UA (93) is also significantly high and indeed the second highest in Central Europe after Russia (95). While Austria's UA (70) is also high, Denmark's UA (23) is the lowest in Europe, followed only by Jamaica (13) and Singapore (8), which indicates high acceptance of unpredictable situations.

Denmark has a significantly low MAS score (16), a characteristic which it shares with other Northern European countries like Sweden (5), Norway (8), the Netherlands (14) and Finland (26). Portugal is the only South European country whose MAS (31) is low, which implies more emphasis on consensus than on individual achievement and personal success. On the contrary, Austria's and Poland's high MAS (79 and 64, respectively) indicate the importance of competition and success. In particular, Austria's MAS is quite high, exceeded only by Hungary (88) and Slovakia (110), the most masculine country in Hofstede's research.

Portugal's LTO (28) is the second lowest in Europe, the lowest being Ireland (24). Denmark and Poland are also characterised by low LTO (35 and 38, respectively), which implies emphasis on quick results and respect for traditions. On the contrary, also considering that 66 is the highest LTO in Hofstede's research, Austria's LTO (60) is quite high and indicates that immediate results are not expected.

As in the other Northern European countries, Denmark's and Austria's scores on IVR are high (70 and 63, respectively) - with Denmark being the second highest in Europe after Sweden (78) which indicates propensity to fun and entertainment. On the contrary, Portugal and Poland score rather low (33 and 29, respectively).

Hall's model (Hall, 1976; Hall \& Reed Hall, 1990) suggested that cultures should be classified as low context communication (LC), in which most of the message is explicitly verbalised, or high context communication (HC), in which more is taken for granted and therefore not verbally conveyed. Compared to the classification on the basis of Hofstede's model, the classification of countries with reference to Hall's model is less straightforward because it is not based on scores, but countries are classified along a cline. In addition, the very concept of LC vs HC is relative, since it clearly depends on the cultures being compared. Further, the number of countries indicated in the model is limited. Given these problematic issues, authors applying Hall's model made different choices. Singh and Pereira (2005, p. 141) provided a list, "in random order", of HC and LC countries. Usunier and Roulin (2010, p. 215) classified the countries in their study into low, lowmedium, medium, medium-high, high context cultures, with the help of expert raters.

Of the countries chosen for the present study, only Denmark and Portugal were indirectly mentioned by Hall and Reed Hall (1990, pp. 6-7), who stated that Scandinavian and Northern European countries are LC, while Mediterranean countries are HC. This is confirmed in Singh and Pereira (2005, p. 141), where Denmark and Portugal are indicated, respectively, as being LC and HC. Singh and Pereira (2005, p. 141) also indicated Austria as being LC, while they did not include Poland - nor any of the East-European countries - in their list. Although Poland was classified as medium-context in Usunier and Roulin (2010, p. 215), it should be noted that the same was true of many other European countries, like Croatia, the Czech Republic, France, Greece, Italy, Romania and the U.K., thus suggesting that Usunier and Roulin's classification is not fine-grained, at least with regard to the European countries. Indeed, the U.K. and Italy were considered in some linguistic 
works as representatives of LC vs HC cultures respectively (e.g. Cucchi, 2010a, 2010b; Katan, 2004, p. 251; 2006; Manca, 2012).

The exact position of the four countries along the LC vs HC cline is problematic. Regarding Austria and Denmark, Hall and Reed Hall (1990) and Würtz (2005, p. 3) indicated the Germanspeaking countries as being the lowest context, followed by the Scandinavian countries, which would imply that Austria is lower context than Denmark. On the contrary, Usunier and Roulin (2010, p. 215) classified Austria as low-medium context and Denmark as LC. It is here noted that the latter classification is in keeping with Hofstede's observation that a link exists between a preference for higher context communication and COL (Hofstede, 2001, p. 212; 2003, p. 60), which would also suggest that Portugal, being higher on COL than Poland, is also higher context than Poland. However, irrespective of their positions along the LC/HC cline, Austria and Denmark can be described as LC cultures, while Poland and Portugal can be considered as representatives of HC cultures (Table 4).

$\mathrm{HC}$ LC

Portugal Denmark

Poland Austria

Table 4. Position of the four countries along Hall's cline

\section{Local versus global corporate identity and the use of English}

The national or local character of the companies included in the corpus was at times apparent in the very company names. The Polish Kalisz, Piątnica, Łowicz and ROTR - Co-operative Creamery in Rypin as well as the Danish companies Barrit and Mammet are named after the toponyms of the city or region where the companies are located. The Austrian Ennstal and Zillertal bear the names of two Austrian valleys, while Kärtnermilch, Pinzgaumilch, Voralberg Milch are compounds where the names of the regions - Kärtner, Pinzgau, Voralberg - are used as premodifiers of Milch (milk). Gmundner and Schärdinger point to the fact that the companies are based in Gmund and Schärding.

The national or local character of the companies was confirmed on the corporate homepages or by a search through their history pages. Example 1 and 2 show, respectively, how the Austrian and the Danish companies position themselves in their respective domestic markets, while Example 3 and 4 refer to the Polish and the Portuguese companies.

(1) $[\ldots]$ the market leader in Austria (Woerle)

'Laendle Milk' is the most popular and best known food brand in Vorarlberg. (Voralberg Milch)

$[\ldots]$ one of the leading food producing and processing companies in Austria. (Gmundner)

$[\ldots]$ the second place in Tirol's milk and cheese market (Zillertal)

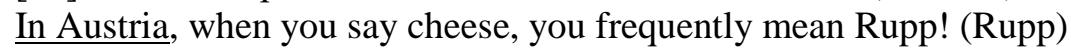

(2) $[\ldots]$ one of the few remaining independent cooperative dairies in Denmark (Barrit)

$[\ldots]$ the only dairy in $[\ldots]$ Bornholm [...][,] an island, [...] situated in the Baltic Sea (St. Clemens)

[...] consists of two Dairy factories situated in small villages in the middle of Jutland, Denmark.

(Mammen Dairy)

[t]he products are sold and distributed under the label [...] Danish Farm (Sædager)

(3) $[\ldots]$ the most valuable brand in the dairy market (Mlekovita)

the biggest producer of cottage cheese on the Polish market (Piątnica)

one of the largest cheese-makers in Poland (Spomlek)

one of the largest manufacturers of a number of processed cheeses in Poland (Sertop)

a leading dairy producer in Poland (Kalisz)

among the leading polish [sic] dairies (Lowicz).

the main sale market is Poland (Polmlek) 
ROTR products are sold mainly on the domestic market (Rotr)

(4) the first company in the Azores [...] to receive [...] [the ISO 22000:2005 certificate]. (Insulac)

$[\ldots]$ is awarded the status 'PME Líder' by the IAPMEI" (Portuguese government institution for the support of small \& medium businesses and innovation) (Saloio)

$[\ldots]$ a major hub of socio-economic dynamics of the entire Douro and Trás-os-Montes region (Paiva)

[has] nationwide coverage (Indulac)

Despite their national or local character, most companies ${ }^{16}$ explicitly state that they target the international market. This is also proven by the English version of their websites, which indicates that the companies are, or wish to become, international players.

To determine the role played by English on corporate websites, a list of the languages utilised for their versions was compiled (Table 5).

\begin{tabular}{|l|l|}
\hline Austrian companies & Versions of the websites \\
\hline 1 Ennstal & German, English, Turkish \\
\hline 2 Gmundner & German, English, Italian \\
\hline 3 Kärtnermilch & German, English \\
\hline 4 Pinzgaumich & German, English \\
\hline 5 Rupp & German, English, French \\
\hline 6 Schärdiger & German, English \\
\hline 7Voralberg Milch & German, English \\
\hline 8 Woerle & German, English \\
\hline 9 Zillertal & German, English \\
\hline Danish companies & Versions of the websites \\
\hline 1 Barrit & Danish, English \\
\hline 2 St. Clemens & Danish, English \\
\hline 3 Mammen Dairy & Danish, English \\
\hline 4 Sædager & Danish, English, German, Russian \\
\hline Polish companies & Versions of the websites \\
\hline 1 Kalisz & Polish, English, German \\
\hline 2 Łowicz & Polish, English \\
\hline 3 Mlekovita & Polish, English \\
\hline 4 Piątnica & Polish, English, German, Russian \\
\hline 5 Polmlek Group & Polish, English, Russian \\
\hline 6 Rotr & Polish, English \\
\hline 7 Sertop & Polish, English, Russian \\
\hline 8 Spomlek & Polish, English, Russian \\
\hline Portuguese companies & Versions of the websites \\
\hline 1 Indulac & Portuguese, English, French, Spanish \\
\hline 2 Insulac & Portuguese, English \\
\hline 3 Lacticinios Paiva & Portuguese, English \\
\hline 4 Saloio & Portuguese, English, Spanish \\
\hline
\end{tabular}

Table 5. Languages on the dairy websites of the four countries

As can be expected of national companies, there were no cases of localisation to address the linguistic needs of consumers in a wide variety of countries, as is the case, for example, in Arla, a company qualifying itself as "a global dairy company and a co-operative owned by dairy

\footnotetext{
${ }^{16}$ The companies which do not mention international markets are Kärtnermilch, Pinzgaumich and Zillertal in Austria; Barrit in Denmark; Łowicz, Piątnica, Polmlek in Poland; Insulac and Saloio in Portugal.
} 
farmers" ${ }^{\prime 17}$, whose website has localised versions targeting 14 countries in their national languages (Figure 1).

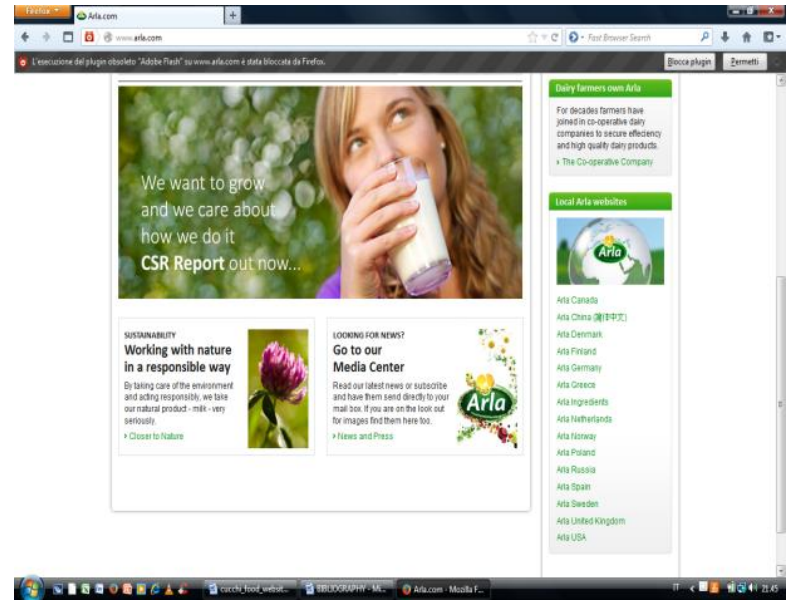

Figure 1. Localised homepage

In a few cases the dairy companies had website versions in one or two other languages beside English and their national language. However, most dairy companies relied exclusively on English to reach international markets. Therefore, English functioned as the only lingua franca, in line with the growing importance played by English both in internal and in external corporate communication shown, for example, in Louhiala-Salminen (2009) and in the special issues of the Journal of Business Communication (Louhiala-Salminen \& Rogerson-Revell, 2010; Rogerson-Revell \& Louhiala-Salminen, 2010) dedicated to language matters in the business domain.

Formally, the texts investigated can be considered as being written in ELF, since their focus is on content rather than on grammatical correctness, in keeping with the ELF paradigm (e.g. House, 2003; Seidlhofer, 2003, 2004, 2007, 2009). Deviations from Standard English, regarding spelling, grammar and lexis (Example 5) were apparent on the homepages under investigation.

(5) Our mission is to make cheese of a unique quality combining the old craftsmanship of cheese making with the newest and most innovative technology available to deliver great quality to our costumers. (Denmark, Mammen Dairy)

MLEKOVITA knows what means to be number 1 (Poland, Mlekovita)

Follow Saiolo. Became a cheese lover (Portugal, Paiva)

We are a production-orientated firm (Austria, Ennstal).

Functionally, the investigated websites are used for conducting business within the international market and can therefore be qualified as BELF (Business English as a Lingua Franca) texts. Thus, their analysis may contribute to BELF studies (e.g. Louhiala-Salminen, Charles, \& Kankaanranta 2005; Charles, 2007; Kankaanranta, 2008; Kankaanranta \& Planken, 2010; Louhiala-Salminen \& Rogerson-Revell, 2010; Rogerson-Revell \& Louhiala-Salminen, 2010; Kankaanranta \& LouhialaSalminen, $2013^{18}$ ).

\footnotetext{
${ }^{17}$ http://www.arla.com/

${ }^{18}$ It is worth mentioning that Kankaanranta and Louhiala-Salminen (2013) suggested that BELF should now be intended as 'English as Business Lingua Franca' rather than 'Business English as a Lingua Franca' because in the former interpretation the domain of use is emphasised.
} 


\section{Analysis and Findings}

A qualitative analysis of the homepages of the companies in the corpus showed great variability in the amount and type of information they offered. It was therefore decided to classify the homepages on the basis of their communicative purpose, with reference to Bhatia's (1993) genre analytical approach. Two genres were thus identified and named cover homepages and noticeboard homepages $^{19}$. Cover homepages bind the web pages together, as covers do in books. In some cases, they feature a phrase which welcomes visitors and sets the tone of the website, similarly to a title (Figure 2). In other cases, they display only the menu of the website, which can be likened to the table of contents in a book (Figure 3), or consist only of images, possibly accompanied only by the company brand, with no additional text (Figure 4).

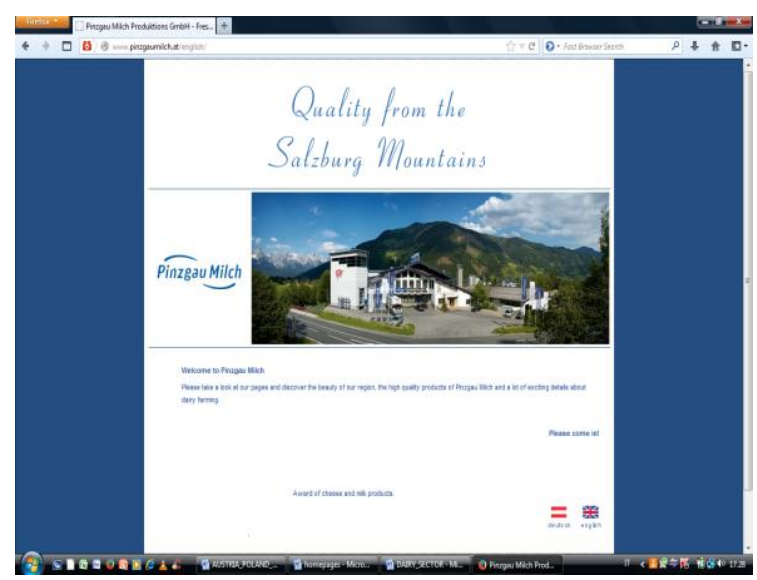

Figure 2. Cover homepage 1

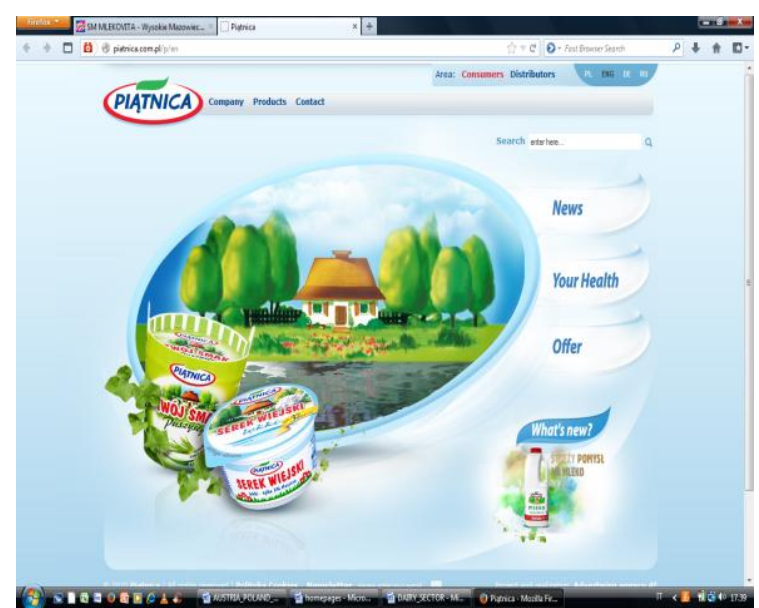

Figure 3. Cover homepage 2

\footnotetext{
${ }^{19}$ The qualification noticeboard for a genre was borrowed from Kankaanranta (2005, p. 207), who used it to refer to email messages whose "communicative purpose was to inform employees of corporate issues".
} 


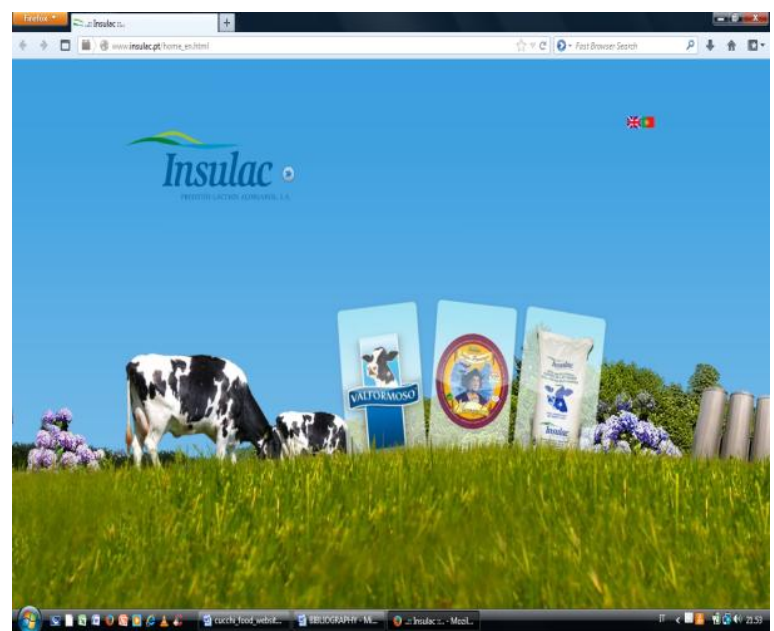

Figure 4. Cover homepage 3

Noticeboard homepages provide information on one or more aspects which the companies arguably regard as necessary for and/or appealing to consumers. At times, only a single corporate aspect is focused on, for example corporate history (Figure 5), company achievements like prizes or certificates (Figure 6), or information on company products (Figure 7). In other cases, the homepages feature information of various types (Figure 8).

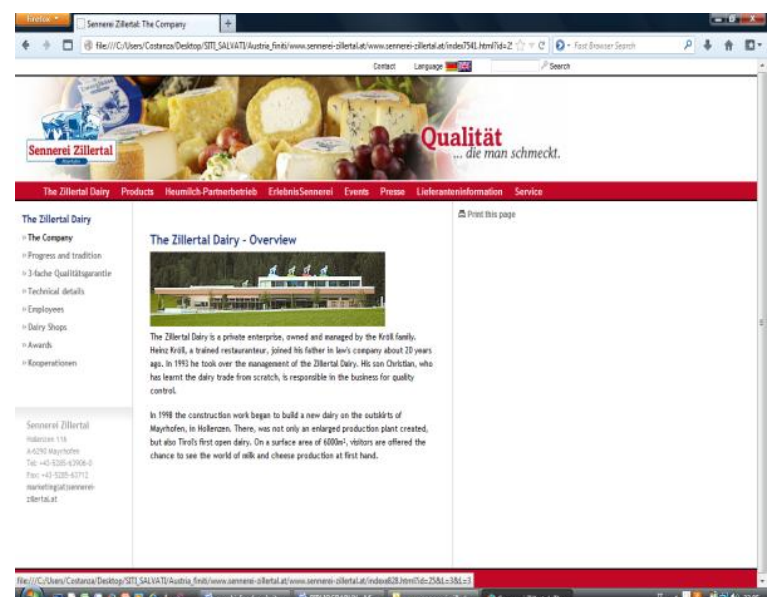

Figure 5. Noticeboard homepage 1

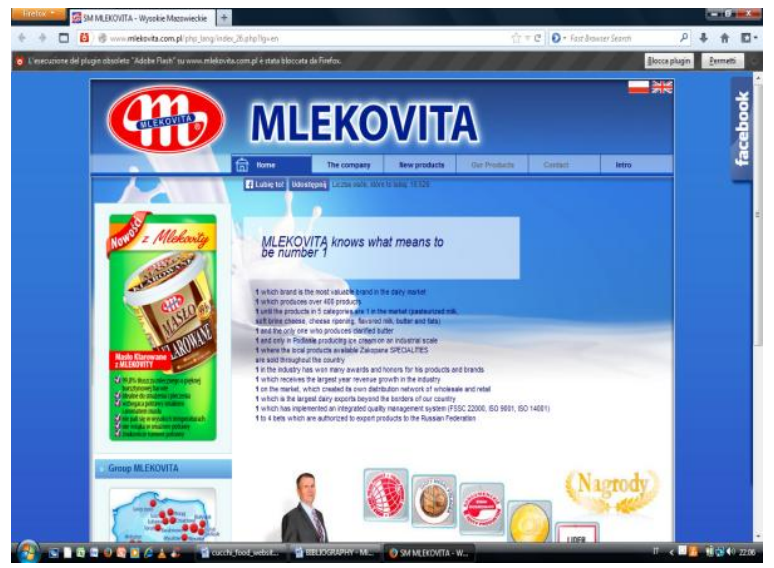

Figure 6. Noticeboard homepage 2 


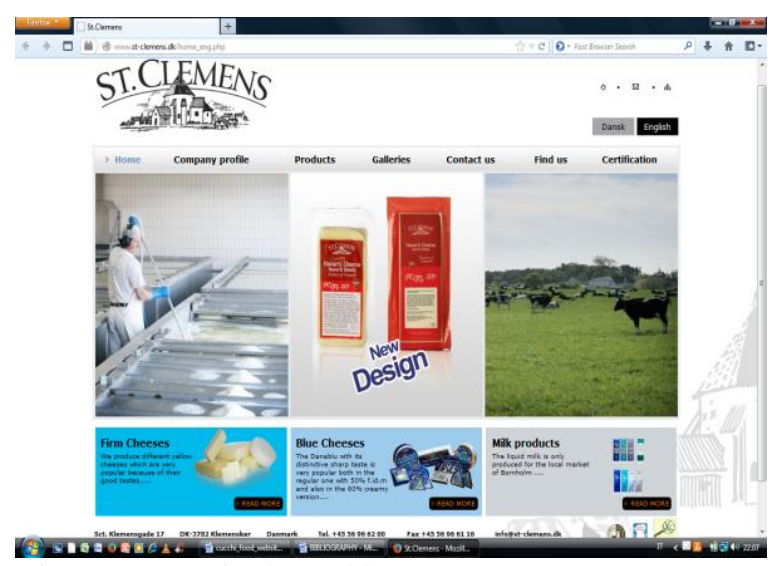

Figure 7. Noticeboard homepage 3

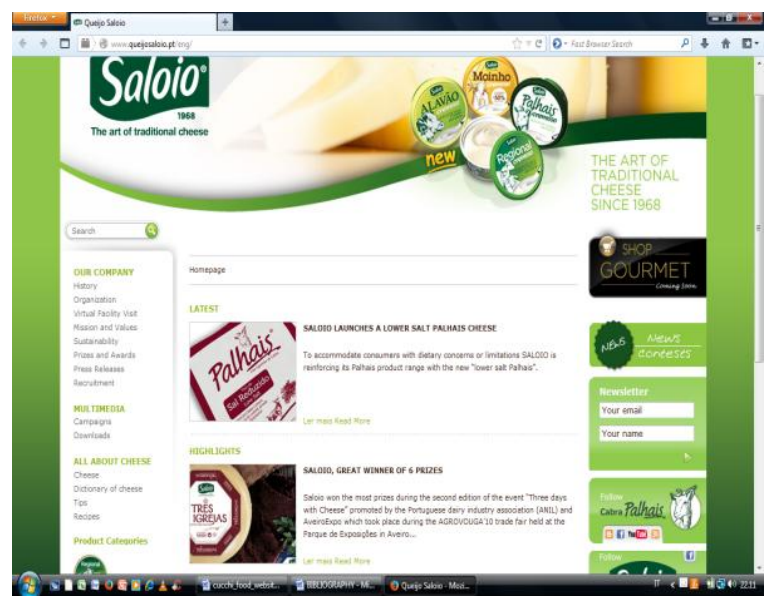

Figure 8. Noticeboard homepage 4

When homepages exhibited features of both cover and noticeboard homepages (Figure 9), they were classified as blended homepages.

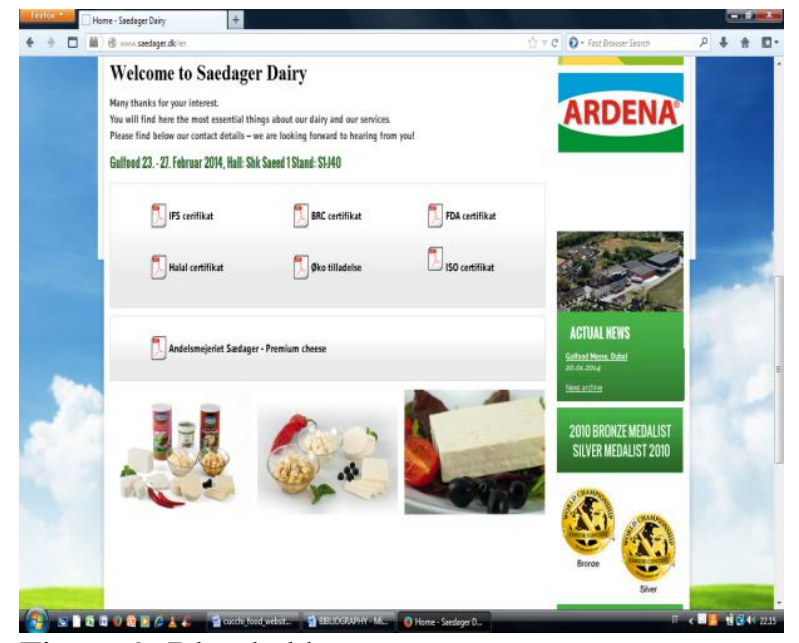

Figure 9. Blended homepage

Within the genres identified, a qualitative analysis was made of the linguistic features which appeared prominent in each country, as the following Subsections illustrate through numerous excerpts from the website texts. Within each Subsection, a distinction is made between cover and noticeboard homepages. Since blended homepages share features of noticeboard and cover homepages, they are considered as representative of both genres. 


\section{Austrian homepages}

Most Austrian companies - Ennstal, Gmundner, Kärtnermilch and Zillertal - have noticeboard homepages. Pinzgaumilch, Woerle and Voralberg have cover homepages, while Rupp and Schärdinger have blended homepages. Only three Austrian companies - Ennstal, Kärtnermilch and Zillertal - irrespective of the genre they belong to, display their contact details on the homepage.

Noticeboard homepages. The noticeboard homepages of most companies - Gmundner, Kärtnermilch, Schärdinger and Zillertal - illustrate their corporate history, providing detailed information about when they were established and the type of company, dates (Example 6) and, at times, the number of farmers and employees and other company data (Example 7). Gmundner, Kärntnermilch, Schärdinger also explicitly mention the noun 'tradition' in their texts (Example 8).

(6) The Schärdinger tradition dates back to $\underline{1900 .}$. In 1900 committed farmers in the Upper Austrian town of Schärding established the Erste Österreichische Zentral Theebutter Verkaufsgenossenschaft, a sales cooperative for Austrian butter, in order to sell their own butter (Schärdinger).

The Zillertal Dairy is a private enterprise, owned and managed by the Kröll family. Heinz Kröll, a trained restauranteur, joined his father in law's company about 20 years ago. (Zillertal)

(7) In 1928 the company was founded under the name "Oberkärntner Molkerei". Kärntnermilch is a farming cooperative and has been located in Spittal/Drau since $\underline{1950}$. Kärntnermilch employs $\underline{180}$ employees. The milk prices that are paid out to over 1,600 farmers and their families in the region is their livelihood. (Kärtnermilch)

[sic] Were there around 40 farmers from Altmünster and Traunkirchen who formed the dairy cooperative back in 1931. (Gmundner)

Company figures 2010:

Volume of milk processing: 305 Mio. $\mathrm{kg}$

Turnover: $€ 170$ Mio.

$\underline{\text { Staff: }} \underline{305}$

Number of milk suppliers: 3,200

Export share: 45\%. (Gmundner)

(8) Dairy farming and cheese production have an ancient tradition in the Salzkammergut. (Gmundner)

Kärntnermilch has been combining tradition with innovation, and quality with sustainability and environmental awareness, for over 80 years.

The Schärdinger tradition dates back to 1900.

Two homepages deviate from this pattern and focus on current identity and activities (Example 9). Ennstal focuses on its principles, while Rupp only mentions its participation in a fair, thus exhibiting more clear-cut features of the cover genre, as will be shown in the following Subsection.

(9) Ennstal Milch KG is an innovative partner for national and international trading companies. We are a production-orientated firm with competitive prices and a clear vision for the future. We feel a strong sense of commitment to nature and the environment in all our activities. 
When mentioned, company achievements are not given particular prominence. Gmundner provides information about prizes in the last paragraph of a text dedicated to corporate history, while Kärntnermilch dedicates to certificates the ninth out of twelve sections (Example 10):

(10) Most strict quality and hygienic demands guarantee the constantly good flavour of the products. This fact is, for instance, testified by the "Gmundner Berg Premium", which was chosen cheese world championship in Wisconsin, US, in spring 2010.

With the exception of Rupp, all the noticeboard homepages display a slogan, at times only in German. The slogans are characterised by an informal flavour conveyed by features of spoken discourse. Schärdinger (Example 11) uses the conjunctions 'so' and 'and', typical of spoken discourse (Carter \& McCarthy, 2006, p. 170), and an exclamation mark, representing an engaged tone, while Ennstal and Zillertal feature suspension marks, which mimic the unfilled pauses of spoken discourse (Carter \& McCarthy, 2006, p. 172), besides stimulating the visitors' curiosity (Examples 12-13). Another feature emerging from the Austrian slogans is reference to fine taste (Examples 13-14). Kärtnermilch's 'Für eine lebenswerte Zukünft' [For a future worth living] is the only slogan which does not present any of these features.

(11) We love what we do, so we do it well. And you can taste it! (Schärdinger)

(12) 'Simply more than milk...' (Ennstal)

(13) Qualität ... die man schmeckt [quality... which one tastes] (Zillertal)

(14) Gmundner Milch. The finest from the Salzkammergut.

Cover homepages. Appeals to taste, to pleasant feelings and to the visitors' curiosity also characterise Austrian cover homepages. Another feature emerging from them is an attempt to establish a personal relationship with visitors by means of salutations and/or engagement markers, the latter being defined as "devices that explicitly address readers, either to focus their attention or to include them as discourse participants" (Hyland, 2004, p. 113). Engagement markers include second person pronouns, imperatives and questions. At times, informal lexis conveys a conversational tone.

Pinzgaumilch, Rupp and Schärdinger address visitors with the salutation 'Welcome to [name of the company]'. Rupp (Example 15) states that the company equates with the pleasure which derives from tasting various kinds of cheese and hints at some unspecified products which are specifically prepared for connoisseurs, thus stimulating the visitors' curiosity. Visitors are invited to access the website with the engagement marker 'you' and the informal noun 'bit'.

(15) Welcome to Rupp and welcome to the world of the enjoyment of cheese in all its diversity.

Here you will find all there is to know about cheese, which is the best bit, and also what else the Alpine dairyman has put to mature for the cheese connoisseur. (Rupp)

Pinzgaumilch accompanies the salutation with explicit invitations to enter the website, worded with the engagement markers 'take a look', 'discover' and 'Please come in!'. As in Rupp, reference is made to enjoyment, both for one's eyes ('beauty') and for one's mind ('exciting'). A sense of curiosity is stimulated by the use of the imperative form 'discover', which suggests something pleasant and unknown. A vague expression, the vague quantifier 'a lot of' (Channel, 1994), conveys an informal flavour (Example 16).

(16) Welcome to Pinzgau Milch 
Please take a look at our pages and discover the beauty of our region, the high quality products of Pinzgau Milch and a lot of exciting details about dairy farming.

Please come in!

Woerle also uses the imperative 'discover', written in capitals, followed by the object 'secrets', arousing the customers' curiosity (Example 17). 'Discover' is repeated in 'Discover cheese', the heading of one of the sections displayed on the menu, and the noun 'delicacies' indicates fine taste. Fine taste is also referred to in the caption 'with real Saffron!' on Voralberg Milch's homepage.

\section{(17) DISCOVER}

The secrets of Salzburg's cheese delicacies (Woerle).

Awards, history, quality and tradition, which were observed on some of the noticeboard homepages, occasionally emerge on cover homepages. Pinzgaumilch features the slogan 'Quality from Salzburg Mountains' and a link to its awards. Similarly, Voralberg Milch displays the captions in Example 18. Tradition features only in the title ' 125 years of tradition' in Woerle's menu.

(18) Best milk quality from the Alps!

The highest awards! (Voralberg Milch).

\section{Polish homepages}

Most Polish companies - Mlekovita, Sertop, Pomlek and Spomlek - have noticeboard homepages, while Piatnica and Rotr have cover homepages. Two companies, Kalisz and Łowicz, have blended homepages. Contacts details are absent on all but one of the Polish homepages, that of Polmlek

Noticeboard homepages. The most evident feature of Polish noticeboard homepages is a focus on current activities, rather than on corporate history and, in most cases, a mention of company achievements, prizes and awards. Mlekovita, whose slogan reads 'MLEKOVITA knows what [sic] means to be number 1', lists its achievements in a text characterised by the repetition of the number 'one'. The text is signed by the company president, who guarantees the company's top position in the dairy sector (Example 19) and medals are displayed as evidence. Polmlek, Sertop and Spomlek mention their top positions as well as awards, certificates and high quality (Example 20). Quality is also suggested in the slogan of one company, Spomlek, which is only in Polish, 'Pasja w doskonałości' (passion for precision). Rather than focusing on their achievements, Kalisz and Łowicz provide information on current company activities in the form of product descriptions and company news.

(19) 1 which brand is the most valuable brand in the dairy market [...]

1 which receives the largest year revenue growth in the industry [...]

1 in the industry has won many awards and honors for his products and brands

1 which is the largest dairy exports beyond the borders of our country

Dariusz Sapinski

The President of the Capital MLEKOVITA

(20) The Group development strategy is based on continuous focus action aimed at reaching the leader position in the dairy sector in Poland. Constant productive potential, quality improvement of the offered products and strengthening of the Warmia brand are some elements of this strategy. (Polmlek)

SERTOP Ltd. has been in existence for over fifty years, and is one of the largest manufacturers of a number of processed cheeses in Poland. The company has implemented an integrated system for the 
production and sale of processed cheese that fulfils the requirements of HACCP, in conformity with the requirements of PN-EN ISO 9001:2001. The company holds the BRC Global Standard Certificate and the IFS (International Food Standard) Certificate. (Sertop)

23.06.2010 Spomlek dairy cooperative wins the Polish Export Leader 2010 award

For the second time in seven years, Spomlek was honored the Polish Export Leader award. (Spomlek).

Another feature of Polish noticeboard homepages is the lack of information on company type and of company figures, Spomlek being the only exception (Example 21).

(21) Company information 31.08.2010 Merger of Spomlek and ESM registered

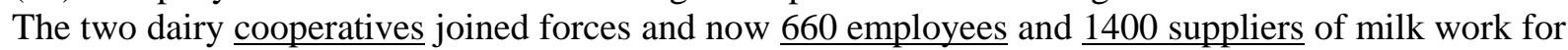
the merged companies. (Spomlek)

None of the homepages is devoted to corporate history and only one company, Sertop, mentions the theme of tradition (Example 22). When reference to the company's foundation is made, such reference is very vague (Example 23) and invariably has the effect of downgrading the information about time to the advantage of the other information provided.

(22) A well proven manufacturing technology, traditional recipes, the best raw materials and strict control at each production stage guarantee high product quality. (Sertop)

(23) SERTOP Ltd. has been in existence for over fifty years, and is one of the largest manufacturers of a number of processed cheeses in Poland.

Dynamic growth and constant development - these are the most accurate words that reflect the type of changes in a company, known in the dairy sector since a certain time as POLMLEK GROUP.

Cover homepages. Kalisz is the only company which uses a salutation, accompanied by two engagement markers in the form of imperatives (Example 24), which explicitly invite visitors to access the website. The phrase "Autumn... something sweet... something delicious", used by Łowicz, may be interpreted as an invitation, albeit much more indirect, to persuade visitors to enter the website by appealing to their senses.

Prizes and quality, shown above to be prominent on Polish noticeboard homepages, also appear on Łowicz's homepage, on which awards can be visualized. The Polish slogan, 'wszystko z mlek' (all made of milk), suggests high quality.

(24) Start a healthy day!

Welcome at OSM Kalisz website.

Feel free to explore our offer.

Rotr and Piatnica display only the menu. The headings of two sections on Piatnica, 'Your health' and 'What's new?', contain engagement markers in the form of the second person possessive adjective 'your' and a question.

\section{Portuguese homepages.}

Out of the four Portuguese companies, two, Paiva and Saloio, have noticeboard homepages. Insulac has a cover homepage, while Indulac has a blended homepage.Contacts details are provided only by Paiva, whose homepage features the company's telephone number, in big characters at the top of the homepage. 
Noticeboard homepages. The theme of tradition runs through all the Portuguese noticeboard homepages. One of Paiva's cheese categories, 'Traditional Cheeses', reads: 'Cow, Goat, Sheep and 3 Milks Blend Cheese, made from the best practices and traditional recipes' and recipes are qualified as 'traditional to cook at home'. Saloio's slogan is 'Saloio 1968 The art of traditional cheese' and Indulac's slogan, which appears in four languages, reads in English 'Martins \& Rebello: More than a century on behalf of the dairy products'. Despite the apparent emphasis on tradition, company history is never disclosed and the companies focus on their achievements, which invariably implies the mention of awards and certificates. Paiva displays its ISO certificate, while Indulac and Saloio dedicate detailed descriptions to them. In particular, Indulac's homepage is entirely dedicated to prizes, as shown in the captions in Example 25. Each caption is followed by a brief but detailed description of the prize. Example 26 shows the text related to 'Côvo Reserva' Cheese.

(25) "Serra do Alvelhe" Cheese awarded with Silver Medal in Wisconsin - USA!!!

"Serra do Alvelhe Reserva" again awarded, now in the World Cheese Awards!

"Côvo Reserva" Cheese in the "Mediterranean Harmonization". (Indulac)

(26) The "Mediterranean Harmonization" first edition was held in Porto and aimed to find the perfect connection between wines from the well-known Portuguese wines brand "Real Companhia Velha", and the recently elected cheese of "Portugal Best Cheeses Contest 2012" sponsored by the National Association of Dairy Manufacturers (ANIL). (Indulac)

Description of products appear on Saloio's and Paiva's homepages (Example 27) and the two companies use engagement markers only in the form of imperatives, respectively to invite visitors to access the descriptions of the various types of cheese and to become Facebook followers (Example 28).

(27) To accommodate consumers with dietary concerns or limitations SALOIO is reinforcing its Palhais product range with the new "lower salt Palhais".

(28) View [cheese category] (Paiva)

Follow Cabra Palhais (Saloio)

Follow Saloio. Became $[$ sic] a cheese lover (Saloio)

Paiva is the only company to hint at the taste of its cheese and to display recipes (Example 29), both of which may be linked to the company's slogan, only in Portuguese, 'A sua mesa o paladar de natureza' ('At your table, the taste of nature').

(29) Innovative range of cheeses for moments of elegance and pleasure, specially prepared for the more demanding palates. (Paiva) 
Creative and delicious recipes using Paiva cheeses. Suggestions from devoted Chefs and traditional recipes to cook anytime at home. (Paiva)

Cover homepages. Indulac features the only salutation in the Portoguese corpus, 'Welcome to more than a century of cheese Tradition!', while Insulac displays no text.

\section{Danish homepages}

Out of the four Danish companies, two, Mammen Dairy and Sædegar have blended homepages. St. Clemens has a noticeboard homepage, while Barrit has a cover homepage. All the homepages display a contact address.

Noticeboard homepages. Danish noticeboard homepages invariably focus on their present activities. St. Clemens provides product descriptions, mentioning fine taste (Example 30), while Mammen Dairy illustrates company organisation, referring to quality and tradition. Although some company figures are disclosed, the company does not indicate when it was founded (Example 31). Sædegar displays links to certificates and medals.

(30) We produce different yellow cheeses which are very popular because of their good tastes.(Barrit)

(31) The company Mammen Dairy Ltd. consists of two Dairy factories situated in small villages in the middle of Jutland, Denmark. In Mammen we manufacture yellow, Danish type cheeses for the domestic market. In Droesbro we make the famous Danish Blue cheese along with Combi-White cheese and traditional types of white cheese. Today we have approx. 90 employees and manufacture 14,000 metric tonnes of cheese a year. Our mission is to make cheese of a unique quality combining the old craftsmanship of cheese making with the newest and most innovative technology available to deliver great quality to our costumers $[\mathrm{sic}]$.

Cover homepages. Both Mammen Dairy and Sædegar display the salutation 'Welcome to [company name]. Sædegar accompanies its salutation, 'Welcome to Sædegar', with engagement markers. Visitors are thanked for accessing the website, addressed with the engagement marker 'you' and introduced to the content of the website, referred to by the informal vague noun 'things' (Example 32). The friendly relationship established with visitors also emerges from an invitation to look at pictures taken at the company's anniversary party, 'Would you like to see pictures from our 125 anniversary party? Then click here', worded with three engagement markers. Engagement markers are also used to direct visitors to the company contact details (Example 33).

(32) Many thanks for your interest.

You will find here the most essential things about our dairy and our services.

(33) Please find below our contact details - we are looking forward to hearing from you!

Barrit displays only images, the slogan 'Craft and tradition', a menu written in English and links in Danish, whose meaning is not accessible to international customers. 


\section{Cross-cultural Analysis and Discussion}

In order to unveil whether the formal and content features described in the previous Section may be related to national cultural preferences as they emerge from past studies on Hall's and Hofstede's models, the findings are here compared and discussed in relation to previous literature. Before addressing the similiarities and differences in the four countries within the two homepage genres which were identified in the corpus, the presence or absence of company details is addressed below, since it was found to be unrelated to homepage genre.

All the Danish companies display contact details on the homepage, which saves the users who want to contact the company the additional effort of looking for the company address on other website pages. Compared to the Danish corpus, contact details appear less frequently on the Austrian homepages. In the Polish corpus the address features only on the homepage of Pomlek, while it never appears on the Portuguese homepages. This finding is thus in keeping with Katan's (2004, p. 267) association between LC cultures and reader orientation. According to this interpretation, LC cultures make it easier for addressees to navigate texts.

Paiva, the only company which displays its telephone number, is Portuguese, in keeping with the fact that Portugal is presumably the highest context country in the corpus, as previously shown. As reported by Katan (2004, p. 262), "[h]igher context communication cultures will tend to prefer more personal communication (e.g. face-to-face, telephone) [...]. LCC cultures, on the other hand, will tend to prefer written explicit information (letters, [...], emails [...])". Usunier and Roulin (2010, p. 191) also claim that websites from LC countries require "more [...] person-to-person-interaction", which could explain the preference for a telephone number rather than an e-mail address.

\section{Noticeboard Homepages}

Company achievements, such as prizes and certificate are given particular prominence on Polish and Portuguese noticeboard homepages. While Austrian companies focus either on corporate history or current activities, Danish, Polish and Portuguese homepages never feature company history. Danish noticeboard homepages tend to focus exclusively on current company activities, by providing descriptions of corporate organisation and company products.

Prominence to prizes and certificates on Polish and Portuguese homepages is in keeping with Poland's and Portugal's much higher PD compared to Austria and Denmark. According to Singh, Zhao and $\mathrm{Hu}$ (2005, p. 130), in fact, high PD societies have "higher expectations for assurance". Therefore, as stated by Singh and Pereira,

[t]o effectively target consumers in high power distance societies, companies need to find ways to let customers know the status of the people or companies they are dealing with, status associated with the product or services they are selling, and how well respected the company is in the target country (Singh \&Pereira, 2005, p. 115).

The need felt by companies to reassure customers by mentioning achievements, prizes and certificates, possibly related to the two countries' high PD, may be enhanced by the two countries' very high UA, prompting companies to portray themselves as experts in their field of activity. High PD and very high UA may also explain the display of a text signed by the company president, which was found on a Polish homepage.

Although company history was associated in past literature to high UA (Singh \& Pereira, 2005, p. 102), thus interpreting company history as a means of reducing customers' uncertainty about the companies' origin, in the present data company history appears in Austria, whose UA is moderately high, but never does in Poland and Portugal, which score higher on UA. A possible interpretation is that, while Polish and Portuguese companies would tend to provide reassurance by mentioning 
prizes, in keeping with Poland's and Portugal's high PD and UA, Austrian companies would do so by illustrating their history, reflecting Austria's moderately high UA and its very low PD. This interpretation seems to be confirmed by the Danish data: Denmark is low on both UA and PD, company history never appears and prizes are mentioned on only one homepage.

The association between the presence of corporate history and STO, according to which company history is interpreted as "an indication of respect for tradition" (Robbins \& Stylianou, 2001, p. 5) typical of STO countries, is not confirmed in the present investigation. Indeed, corporate history features only in Austria, the only country whose LTO is high, while it never features in Denmark, Poland and Portugal, characterised by STO.

Although the theme of tradition appears in all the national corpora, arguably because of the national or local origin of the products, it is in the Portuguese corpus that it is more prominent, in the texts as well as in the slogans. The importance of tradition is also reflected in the links to recipes, usually shared by people from the same country, which feature only on a Portuguese homepage. This seems in keeping with Portugal's very low IDV score, which arguably leads to highlight shared values.

Since high UA countries "value conservatism and traditional beliefs", Singh and Pereira (2005, p. 101) recommend that the theme of tradition should be emphasised on the localised websites aimed to high UA countries. If Portugal's very high UA would explain the central role of tradition on the Portuguese homepages, Poland's UA, which is also very high, would not explain the reason why tradition is not prominent on the Polish homepages.

The tendency observed in the Austrian and Danish corpora to focus on their objective past or present, in the form of company history, company organisation, company products and company figures, rather than on prizes, seems in keeping with the observation that LC websites generally have "informative content and rather factual messages" (Usunier \& Roulin, 2010, p. 195) as compared to HC websites. On the contrary, the claims that in HC cultures advertisements "are characterised by indirect verbal expressions and are implicit, indirect, [...], modest, and even ambiguous" (Singh \& Pereira, 2005, p. 142) and that "the sales pitch is subdued [...] and makes implicit claims rather than explicit claims on product superiority" (Singh \& Pereira, 2005, p. 145) is not confirmed in the present data.

\section{Cover Homepages}

Despite the lack of process sharing (Halliday \& Hasan, 1989, p. 58), namely the impossibility of the addressees to participate in the making of the web texts, the Austrian homepages display a markedly dialogic style, characterised by one or more of the following linguistic features: salutations and engagement markers such as 'you'/'your', imperatives and questions, which convey the impression of a dialogue, vague language, typical of conversations among friends, exclamation marks and suspension marks, which represent features of spokenness. These dialogic and conversational features suggest equality among discourse participants, in keeping with Austria's PD, the lowest in Hofstede's research.

A dialogic style also characterises two out of four of the Danish homepages and Denmark is the other country in the corpus whose PD is low. On the contrary, the Polish and Portuguese data can be considered in keeping with the fact that high PD societies "have lower expectations about responsiveness and empathy" (Singh, Zhao, \& Hu, 2005, p. 130), thus confirming an association between low PD, on the one hand, and higher interaction with the addressees (Dekker, Rutte, \& van den Berg, 2008; Meeuwesen, van den Brink-Muinen, \& Hofstede, 2009; Loukianenko Wolfe, 2008) and more informal language (Katan, 2004 p. 274; Bjørge, 2007; CUCCHI, 2010a; Kang \& Mastin, 2008), on the other hand.

Regarding the link between low PD and informality, it should be noted that vague language, associated in the linguistic literature with informality (e.g. Crystal \& Davy, 1975, p. 112; Carter \& 
McCarthy, 1997, p. 16), features only on the Austrian and Danish homepages. In addition, it is interesting to note that Kalisz, the only company in the Polish corpus which utilises an imperative form to invite visitors to enter its website, prefers the more indirect form 'Feel free to explore our offer' to the bold imperative or [please + imperative], used by the Austrian companies Woerle and Pinzgaumilch and by the Danish Sædager. With reference to politeness theory (Brown \& Levinson, 1987), a more indirect form suggests more deference to the addressee and a lower degree of imposition, in keeping with Poland's much higher PD as compared to Austria's and Denmark.

While the salutation 'Welcome to [name of the company]' appears on the Austrian, Danish and Polish homepages, the only deviating pattern, 'Welcome to more than a century of cheese Tradition!', features in the Portuguese Indulac, which replaces the company's individual identity with 'Tradition', in keeping with Portugal's low IDV. The centrality of the theme of tradition is also observed in the slogans on the Portuguese cover homepages.

In the Austrian corpus, salutations, invitations to customers and slogans frequently contained appeals to 'enjoyment'(Albers-Miller \& Gelb, 1996, p. 59), which are only occasionally present in the other corpora. While this could be related to Austrian's high Indulgence score, the enjoyment appeal features only once in the Danish corpus and, therefore, it does not appear to be related to the Danish Indulgence score, which is higher than the Austrian one. However, past literature associated appeals to enjoyment (Albers-Miller \& Gelb, 1996, p. 61; Singh \& Pereira, 2005, p. 131) and the 'effective' appeal, which comprises the description of food as tasty (Albers Miller \& Gelb, 1996, p. 59), to high MAS (Albers-Miller \& Gelb, 1996, p. 61; Singh \& Pereira, 2005, p. 131). This interpretation is confirmed in the present investigation, since Austria's MAS score is considerably higher than that of the other countries in the corpus.

When present, the Polish slogans exhibit appeals to 'safety', defined by Albers-Miller and Gelb (1996, p. 59) as "security (from external threats), carefulness, caution [...] absence of hazards, potential injury or other risks, guarantees, warranties, manifacturers' reassurance"), in keeping with their hypothesised association between this appeal and high UA. However, appeals to safety are absent in Portugal, whose UA is higher than Poland's.

Cover homepages exhibiting only an image or the menu are found exclusively in the Polish and Portuguese corpora. Nothing is immediately revealed and it is up to website visitors to make additional efforts to get information about the companies by choosing which sections to explore. This may be linked to the fact that, compared to Austria and Denmark, Poland and Portugal are markedly higher context cultures and, therefore, less reader-oriented.

\section{Conclusion}

The qualitative analysis of the English homepages of local dairy companies based in four European countries has shown considerable differences in terms of content and form. This suggests that, despite globalisation, cultural differences on a national basis are still noticeable in Europe, a geographically delimited territory, where one could assume that cultural differences among nations are not marked. In particular, national corporate websites, which may be considered as BELF texts, exhibit cultural national traces, as does spoken BELF (e.g. Louhiala-Salminen, Charles, \& Kankaanranta, 2005; Charles 2007), despite the global nature of the Internet. A tension is thus created between the global reach of the Internet, which is ensured by the use of English, a common language used to connect with international customers, and the culture-bound nature of the content and linguistic forms which appear on the homepages of national and local companies.

Despite the fact that Hofstede's and Hall's models were devised before the market globalisation and technological innovations took place, the models have proven helpful for the interpretation of some of the linguistic features displayed on the homepages of the four countries, although not all the associations emerged in past studies have been confirmed in the present investigation. 
It should be noted that, as reported by Singh and Pereira (2005, p. 5), many studies "confirm that country-specific web content enhances usability, reach and web site interactivity, leading to more web traffic and business activity" and that their own research indicates "that web sites that are customized to specific countries enjoy strong advantages compared with those that are not". This supports the need for versions in a variety of languages with content and design elements tailored to specific cultures. Simultaneously, this raises the question about the extent to which culture-bound content, expressed in English in a register which is also culture-bound, is effective in attracting international consumers.

Associated to this is the question of which content and forms are appropriate for the English website versions of small- and medium-sized companies, which, having limited financial resources, use English, and occasionally one or two additional languages, to reach international consumers. One Danish company in the corpus, Sædegar, seems to have solved the problem by blending features associated with different cultures. Its homepage displays pdf certificates of the prizes won, which is believed to be typical of high PD and high UA countries, and is characterised by a highly dialogic style, possibly so as to attract visitors from low PD countries. Whether this strategy is effective to reach consumers from a wide variety of countries is an open question.

Methodologically, the study shows that an accurate bottom-up, inductive approach rooted in actual texts reveals linguistic features which may be missed out when applying a top-down, deductive approach which proceeds from hypotheses formulated on the basis of the cultural dimensions, as is the case in marketing studies. It is therefore claimed that linguistic research can contribute significantly to marketing studies, by providing a close examination of web texts and by identifying refined linguistic markers possibly associated with cultural differences, such as engagement markers, vague language and salutation forms, and by showing how they interact in actual texts.

A further important contribution of linguistic research to the study of websites consists in recording examples of language in use, which are lacking in the marketing studies considered for the present investigation. This may assist researchers in the field of linguistics, marketing and intercultural communication as well as language students specialising in marketing and digital communication, enhancing their comprehension of national similarities and differences. 


\section{References}

Aaltonen, S.. (2005). Exploring Corporate Websites as a Setting for ELF research: The Case of Ostrobothnian Export Companies. Nordic Journal of English Studies, 5(2), 189-220.

Albers-Miller, N. D., \& Gelb, B. D. (1996). Business Advertising Appeals as a Mirror of Cultural

Dimensions: A Study of Eleven Countries. Journal of Advertising, XXV(4), 57-70.

Arla, http://www.arla.com/

Avery, A. E., Baradwaj, B. G., \& Singer, D. D. (2008). An Examination of Hofstede's Cultural Factors in Explanation of Differences in Citibank International Retail Banking Web Sites. Journal of Business \& Economics Studies, 14(2), 73-90.

ANIL - Portuguese National Association of Dairy Products (Assocàcio Nacional dos Industriais de Lacticinios), http://www.anilact.pt/

Baack, D. W., \& Nitish, S. (2007). Culture and web communications. Journal of Business Research, 60, 181-188.

Bhatia, V.. (1993). Analysing Genre. Cambridge: Cambridge University Press.

Bjørge, A. K. (2007). Power distance in English lingua franca email communication. International Journal of Applied Linguistics, 17(1), 60-80.

Brown, P., \& Levinson, S.. (1987). Politeness: Some Universals in Language Usage. Cambridge: Cambridge University Press.

Carter, R., \& McCarthy, M. (1997). Exploring Spoken English. Cambridge: Cambridge University Press.

Carter, R., \& McCarthy, M. (2006). Cambridge Grammar of English: A Comprehensive Guide. Spoken and Written English Grammar and Usage. Cambridge: Cambridge University Press.

Cesiri, D. (2011). Intercultural Communication in Business Promotion through Corporate Websites: the case of Kraft Foods and Nestlè in Europe and Asia. In R. Salvi \& H. Tanaka (Eds.), Intercultural Interactions in Business and Management. (pp. 91-117). Bern: Peter Lang.

Channell, J. (1994). Vague Language. Oxford: Oxford University Press.

Charles, M. (2007). Language matters in global communication: Article based on ORA lecture, October 2006. Journal of Business Communication, 44(3), 260-282.

Clyne, M. (1994). Intercultural Communication at Work: Cultural Values in Discourse. Cambridge: Cambridge University Press.

Conaway, R. N., \& Wardrope, W. (2010). Do their words really matter? Thematic analysis of U.S. and Latin American CEO letters. Journal of Business Communication, 47(2), 141-168.

Crystal, D., \& Davy, D. (1975). Advanced Conversational English. London: Longman.

Cucchi, C. (2010a). Vague expressions in the European Parliament: A Marker of Cultural Identity?". In G. Garzone \& J. Archibald (Eds.), Discourse, Identities and Roles in Specialized Communication (pp. 85-107). Bern: Peter Lang.

Cucchi, C. (2010b). Hofstede's cultural dimensions: Italian national identity in ELF usage. Cultus, The Journal of Intercultural Mediation and Communication, 3, 137-158.

Cucchi, C. (2011). Language and national identity. Applications of Hofstede's dimensions. In K. Ciepiela (Ed.), Identity through a Language Lens (23-34). Frankfurt am Main: Peter Lang.

Cucchi, C. (2012). Hofstede's cultural dimensions in ELF company websites of European countries: lexical choices in Sweden and Greece. In R. Facchinetti (Ed.), A Cultural Journey through the English Lexicon (153-181). Newcastle upon Tyne: Cambridge Scholars Publishing.

Danish Dairy Board (Mejeriforeningen), http://www.mejeri.dk/

Dekker, D.M., Rutte, C.G., \& Van den Berg, P.T. (2008). Cultural differences in the perception of critical interaction behaviors in global virtual teams. International Journal of Intercultural Relations, 32, 441-452.

European Dairy Association (EDA), http://www.euromilk.org/eda/index.aspx

European Food Information Council (EUFIC), http://www.eufic.org/index/en/

Expo 2015, http://en.expo2015.org/expo-2015 
Fletcher, R. (2006). The impact of culture on web site content, design, and structure. An international and a multicultural perspective. Journal of Communication Management, 10(3), 259-273.

Facchinetti, R. (2013). The Interactivity of Corporate Websites: A Comparative Study. Textus, English Studies in Italy, The use of English in Intercultural Professional Settings: Virtual Encounters and Identities, XXVI(1), 45-55.

Gatti, M. C. (2011). Reconstructing Time and Space to Persuade: An Eastern-European Case-study of Organizational Discourse. In R. Salvi \& H. Tanaka (Eds.), Intercultural Interactions in Business and Management (pp. 119-143). Bern: Peter Lang.

Gatti, M. C. (2013). The Construction of Company Identity through Memory. Specialised Metaphorical Meanings for Pastness on Italian Business Web Pages. Textus, English Studies in Italy, The use of English in Intercultural Professional Settings: Virtual Encounters and Identities, XXVI(1), 69-79.

Guillén-Nieto, V. (2009). Crossing Disciplines in Intercultural Communication Research. In V. Guillén-Nieto, C. Marimón-Llorca, \& C. Vargas-Sierra (Eds.), Intercultural Business Communication and Simulation Gaming Methodology (pp. 29-63). Bern: Peter Lang.

Hall, E.T. (1976). Beyond Culture. Garden City, New York: Doubleday.

Hall, E.T., \& Reed Hall, M. (1990). Understanding cultural differences: Germans, French and Americans. Yarmouth, Maine: Intercultural Press.

Halliday, M.A.K., \& Hasan, R. (1989). Language, Context and Text: Aspects of Language in a Social-Semiotic Perspective. Oxford: Oxford University Press.

Hatipoğlu, Ç.. (2006). Computer mediated Language and Culture: Salutations and Closings in British and Turkish 'Call for papers' Written in English. Studies About Languages (Kalbu Studijos), 8, 31-38. Retrieved from http://www.ceeol.com/aspx/SearchArticles.aspx

Hofstede, G. (1980). Culture's Consequences: International Differences in Work-Related Values. Beverly Hills CA: Sage Publications.

Hofstede, G. (2001). Culture's Consequences. Comparing Values, Behaviors, Institutions and Organizations Across Nations. Thousand Oaks: Sage Publications.

Hofstede, G. (2003) (first published 1991). Cultures and Organizations, Software of the Mind, Intercultural Cooperation and its Importance for Survival. London: Profile Books.

Hofstede, G., Hofstede, G. J., \& Minkov, M. (2010). Cultures and Organizations, Software of the Mind, Intercultural Cooperation and its Importance for Survival. New York: McGraw Hill.

House, J. (2003). English as a Lingua franca, a threat to multilingualism?, Journal of Sociolinguistics, 7(4), 556-478. Retrieved from http://uk-online.unikoeln.de/remarks/d5134/rm2169656.pdf

Hyland, K. (2004). Disciplinary Discourses. Social Interactions in Academic Writing. Ann Arbor: The University of Michigan Press.

Isaksson M., \& Jørgensen Flyvholm, P.E. (2010). Communicating Corporate Ethos on the Web. The Self-Presentation of PR Agencies. Journal of Business Communication, 47(2), 119-140.

Jones, S.L. (2007). Evolution of Corporate Homepages 1996 to 2006. Journal of Business Communication, 44(3), 236-257.

Kankaanranta, A. (2005). "Hej Seppo, could you pls comment on this!" - Internal Email Communication in Lingua Franca English in a Multinational Company. Jyväskylä: Centre for Applied Language Studies, University of Jyväskylä, Retrieved from https://jyx.jyu.fi/dspace/bitstream/handle/123456789/18895/9513923207.pdf?sequence=1.

Kankaanranta, A. (2008). Business English Lingua Franca in intercultural (business) communication. Language at Work - Bridging Theory and Practice, 3(4), 1-10. Retrieved from http://ojs.statsbiblioteket.dk/index.php/law/article/view/6193/5381. 
Kankaanranta, A., \& Planken, B. (2010). Belf Competence as Business Knowledge of Internationally Operating Business Professionals. Journal of Business Communication, 47(4), 380-407.

Kankaanranta, A., \& Louhiala-Salminen, L. (2013). 'What language does global business speak?' The concept and development of BELF, Ibérica, 26, 17-34. Retrieved from http://www.aelfe.org/documents/01_26_Kankaanranta.pdf

Katan, D. (2004). Translating Cultures: An Introduction for Translators, Interpreters and Mediators. Manchester: St. Jerome.

Katan, D. (2006). "It's a Question of Life or Death: Cultural Differences in Advertising Private Pensions". In N. Vasta (Ed.), Forms of Promotion Texts, Contexts and Cultures (pp. 55-80). Bologna: Pàtron Editore.

Louhiala-Salminen, L., Charles, M., \& Kankaanranta, A. (2005). English as a lingua franca in Nordic corporate mergers: Two case companies. English for Specific Purposes, 24(4), 401-421.

Louhiala-Salminen, L. (2009). Business Communication. In F. Bargiela-Chiappini (Ed.), The Handbook of Business Discourse (pp. 305-316). Edinburgh: Edinburgh University Press.

PIM - Polish Chamber of Milk (Polska Izba Mleka), http://izbamleka.pl/

Louhiala-Salminen, L., \& Rogerson-Revell, P. (2010). Language Matters. An Introduction, Journal of Business Communication. 47(2), 91-96.

Loukianenko Wolfe, M. (2008). Different cultures - Different discourses? Rhetorical patterns of business letters by English and Russian speakers. In U. Connor, E. Nagelhout, \& W. Rozycki (Eds.), Contrastive Rhetoric. Reaching to Intercultural Rhetoric (pp. 87-120). John Benjamins: Amsterdam.

Manca, E. (2012). Translating the Language of Tourism across Cultures: From Functionally Complete Units of meaning to Cultural Equivalence. Textus, Tourism and Tourists in Language and Linguistics, XXVI(1), 51-68.

McSweeney, B. (2002). Hofstede's model of national cultural differences and their consequences: A triumph of faith - a failure of analysis. Human Relations, 55(1), 89-118.

Meeuwesen, L., van den Brink-Muinen, A., \& Hofstede, G. (2009). Can dimensions of national culture predict cross-national differences in medical communication? Patient Education and Counseling, 75, 58-66.

PIM - Polish Chamber of Milk (Polska Izba Mleka), http://izbamleka.pl/

Poppi, F. (2012). Politeness Strategies and Cultural Differences in Email Communication. In F. Poppi, Global Interactions in English as a Lingua Franca. How written communication is changing under the influence of electronic media and new contexts of use (179-199). Peter Lang: Bern.

Robbins, S. S., \& Stylianou, A. C. (2002). A Study of Cultural Differences in Global Corporate Web Sites. Journal of Computer Information Systems, Winter 2001-2002, 3-9.

Rogerson-Revell P., \& Louhiala-Salminen, L. (2010). Language Matters. An Introduction, Part 2. Journal of Business Communication, 47(4), 375-379.

Seidlhofer, B. (2003). A concept of International English and related issues: From 'real English' to 'realistic English'? Language Police Division, DG IV _ Directorate of School, Out-of-School and Higher Education Council of Europe, Strasbourg, 1-28. Retrieved from http://www.coe.int/t/dg4/linguistic/source/seidlhoferen.pdf.

Seidlhofer, B. (2004). Research perspectives on teaching English as a Lingua Franca. Annual review of Applied Linguistics, 24, 209-239. Retrieved from http://people.ufpr.br/ clarissa/pdfs/ELFperspectives_Seidlhofer2004.pdf.

Seidlhofer, B. (2007). Common property: English as a Lingua Franca in Europe. In J. Cummins \& C. Davison (Eds.), International handbook of English language teaching (pp. 137- 153). New York: Springer.

Seidlhofer, B. (2009). Common ground and different realities: World Englishes and English as a lingua franca. World Englishes, 28(2), 236-245. 
Singh, N., Zhao, H., \& Hu, X. (2003). Cultural adaptation on the web: A study of American companies' domestic and Chinese websites. International Journal of Global Information Management, 11(3), 63-80.

Singh, N., Zhao, H., \& Hu, X. (2005). Analyzing the cultural content of web sites. A cross-national comparison of China, India, Japan, and US. International Marketing Review, 22(2), 129-146.

Singh, N., \& Pereira, A. (2005). The Culturally Customized Web Site. Customizing Web Sites for the Global Marketplace. USA: Elsevier.

The Dairy Site, http://www.thedairysite.com/

Turnbull, J. (2008). Language and Culture in Corporate Websites. In J. Bamford \& R. Salvi (Eds.), Business Discourse: Language at Work (pp. 17-34). Roma: Aracne.

Turnbull, J. (2011). How 'Glocal' is Corporate discourse? A Case Study of a Multinational's Website. In R. Salvi \& H. Tanaka (Eds.), Intercultural Interactions in Business and Management (pp. 75-90). Bern: Peter Lang.

Usunier, J., \& Roulin, N. (2010). The Influence of High- and Low-Context Communication Styles on Design, Content, and Language of Business to Business Web Sites. Journal of Business Communication, 47(2), 189-227.

Vasta, N. (1998). The semantics of conflict: the system of power and solidarity in official statements during the Gulf War. In M. M. Mechel, N. Vasta, \& C. Chiaruttini Leggeri (a cura di), Rappresentazioni dell'identità: la dimensione linguistica del conflitto (pp. 115-153). Quaderni Linguistici del Dipartimento di Scienze politiche dell'Università degli studi di Trieste. Trieste: Cedam.

Vergaro, C. (2004). Discourse strategies of Italian and English sales promotion letters. English for Specific Purposes, 23, 181-207.

$\begin{array}{llll}\text { VÖM } & - & \text { Austrian } & \text { Dairy }\end{array}$

(Vereinigung Österreichischer Milchverarbeiter), http://www.voem.or.at/

Williamson, D. (2002). Forward from a critique of Hofstede's model of national culture. Human Relations, 55(11), 1373-1395.

Würtz, E. (2005). A Cross-Cultural Analysis of Websites from High-Context Cultures and LowContext Cultures. Journal of Computer-Mediated Communication, 11(1), article 13. Retrieved from http://polyuassignment.wikispaces.com/file/view/407_ICCWebsites+High+\%26+Low+Contexts.pdf, 1-25.

Zhao, W., Massey, B.L., Murphy, J., \& Fang, L. (2003). Cultural Dimensions of Website Design and Content. Prometheus, 2l(1), 75-84. Retrieved from http://web.biz.uwa.edu.au/staff/jmurphy/Cultural_Dimensions.pdf

\section{Corpus}

Austria

Ennstal http://www.ennstalmilch.at/en/

Gmundner http://www.gmundner-milch.at/?id=2191\&L=2

Kärtnermilch http://kaerntnermilch.at/de/unternehmen/die-molkerei/facts-figures

Pinzgaumich http://www.pinzgaumilch.at/pinzgaumilch/english/

Rupp http://www.rupp.at/index.php?id=1\&L=1

Schärdiger http://www.schaerdinger.at/

Voralberg Milch http://www.vmilch.at/en/

Woerle http://www.woerle.at/en/

Zillertal http://www.sennerei-zillertal.at/index.php?id=25\&L=3

Denmark

Barrit http://barritmejeri.dk/en/ 
St. Clemens http://www.st-clemens.dk/home_eng.php

Mammen Dairy http://www.mammenost.dk/home-32562.htm

Sædager http://www.saedager.dk/en/113043-About-Sdager

Poland

Kalisz http://www.osm.kalisz.pl/en

Łowicz http://www.mleczarnia.lowicz.pl/lowicz/index.php?strona=home-en

Mlekovita http://www.mlekovita.com.pl/php_lang/index_26.php?lg=en

Piątnica http://piatnica.com.pl/p/en

Polmlek Group http://www.polmlek.com/en/start

Rotr http://www.delik.com.pl/en/index.php

Sertop http://www.sertop.com.pl/en,32, about-the-company.html

Spomlek http://www.spomlek.pl/home.php

Portugal

Indulac http://www.indulac.pt/default.asp

Insulac http://www.insulac.pt/home_en.html

Lacticinios Paiva http://www.lacticiniospaiva.pt/en/home.aspx

Saloio http://www.queijosaloio.pt/eng/ 